\title{
An economic study on maize residue practices in Dinajpur district
}

\author{
M. T. Uddin* and A. Goswami \\ Department of Agricultural Economics, Bangladesh Agricultural University, Mymensingh-2202, Bangladesh \\ *Email: tajbau@yahoo.com
}

\begin{abstract}
The study was conducted to examine the maize residue practices and its impact on productivity, profitability on succeeding crop and farmers' livelihood. A total of 60 farmers from Ghoraghat upazila of Dinajpur district were selected randomly for data collection. Descriptive statistics (i.e., sum, average, percentages, ratios, etc.), profitability analysis and logit model were employed to achieve the objectives. In case of pattern of maize residue retention, whole retention method was the highest and it was 78.2 percent. The whole retention of maize residue was found higher in far distance plots from homestead and it was 82.8 percent. The highest utilization of maize residue was identified as organic fertilizer and it was 82.2 percent. Due to maize residue practices, both crop and livestock were benefited through resource interdependences. The productivity, profitability and annual income of succeeding crop i.e., Aman rice were higher due to maize residue practicing. The result of logit regression model shows that the farm size, age of household head, farm income and non-farm income were found as significant variables in explaining the maize residue adoption. The access on human capital, social capital, financial capital, natural capital and physical capital were increased by $23.5,22.7,26.7,10.6$ and 18.8 percent, respectively due to the practice of maize residue in comparison to traditional farming. The study recommended that farmers could enhance their livelihood if they get proper training facilities and extension services for maize residue management.
\end{abstract}

Keywords: Economic study, Maize residue, Farmers' livelihood

\section{Introduction}

Bangladesh is a small developing country where most of the people earn their living from agriculture. Maize is the third most important cereal crop in Bangladesh, after rice and wheat. It is a major cash crop, and is one of the major sources of employment, especially for smallholders and women. Maize is most commonly used in the poultry and fish feed industries for baking and other foods for human consumption. The nutritional value of maize, its economic importance and incredibly diverse uses are significant not only in Bangladesh, but across every region of the world. Maize cultivation is being rapidly expanding both in Rabi and Kharif season. In 2012-13 cropping season, it was grown on an estimated area of 580 thousand acres with an annual production of 1548 thousand metric tons (BBS, 2013). The developed countries are capable to deal with low soil fertility through supply of nutrients in sufficient amounts as chemical fertilizers. However, this is not possible because of the high costs of fertilizers in many countries. As a result, farmers use both the available organic sources and the affordable amount of chemical fertilizers to cut down the high cost of chemical fertilizers for higher crop yields. However, due to energy shortages, increased fertilizer cost, deterioration of soil health and environmental concerns, the use of organic manures has again become important (Yaduvanshi, 2003). The organic matter or crop residue helps to recycle the nutrients to correct their deficiencies. Studies indicated that use of organic sources can help to maintain a better N:P ratio and higher yield (Bakhtiar et al., 2002 and Khanam et al., 2001). Crop residues are materials left in an agricultural field or orchard after the crop has been harvested. These residues include stalks, stems, leaves and seed pods. Maize residue is mainly consisted of straw, husks, skins and trimmings, cobs and bran. Crop residue plays an essential role in nutrient recycling to improve soil quality and ensure higher level of crop productivity. It can be composed by various methods on the farm itself and used there in the field for mulching. Incorporation of residue in the field alters the soil environment, which in turn influences the microbial population and activity in soil and subsequent nutrient transformations. Crop residue helps to reduce water and wind erosion, save irrigation water and fertilizer, increase plant available moisture, improve soil fertility condition and enhance crop productivity. Crop residues are either harvested as fuel, animal bedding or are burnt in the field. So, crop residue management is the best alternative to increase the productivity with maintaining the soil quality. 
Conventional agronomic practices cannot meet the triple objectives of (i) producing enough food for the burgeoning population, (ii) minimizing agriculture induced degradation of natural resources, and (iii) maintaining environmental quality and ecosystem services. Crop residue offers sustainable and ecologically sound alternatives for meeting the nutrient requirements of crops, and improving soil and environmental quality. At this stage, crop residue increases the yield of crop production. To feed the increased population of Bangladesh, there is no option but to manage crop residue properly. A few studies concerning specific aspect of crop residues have been performed by different researchers which are: Shafi et al. (2007) reported that crop residues incorporation significantly increased grain yield of maize compared with the residues removed treatment; Burgess et al. (2002) reported that the production of maize returns large amounts of residues to the soil at the harvest and improves soil quality; Pretty et al. (2002) explored the possibility of using of plant products such as crop residue (e.g., maize cobs, cereal straw, rice husks) or wastes (e.g., chicken manure) for combustion in electricity generation through smallscale gas turbines among potential fields to explore for this purpose; Krishna et al. (2004) conducted study on rice residue management options and effects on soil properties and crop productivity and found that proper management of residues can warrant the improvements in soil physical, chemical and biological properties and sustain productivity of rice-wheat cropping system; Singh et al. (1998) reported that retaining crop residue often improves the capacity of soil to store water and could be improve crop yield; Larson et al. (1972) showed that different types of crop residues such as maize stover, oat straw, alfalfa, saw dust and brome grass had highly effects on soil organic matter content; Latham (1997) found that crop residues are also used for other purposes, such as to provide vital livestock feeds during long dry seasons, fuel and construction material; Regmi et al.(2002) found that introduction of crop residue in the soil offers the best means to restore carbon in agriculture soils; Timsina et al. (2010) reported that the establishment of maize after rice with reduced or no tillage and retaining of crop residues, could help to conserve soil organic matter and maintain soil fertility if improved nutrient management is practiced.

The above literature review indicates that most of the studies attempted impact of crop residues on soil health and crop yield, impact of incorporation and burning of crop residue, etc. There is no work regarding present status of maize residue practices and its impact on farmers' livelihood in order to formulate policy options. Therefore, the specific objectives set for the study are as: (i) to identify the farmers' perception for the use of maize residue with resource recycling between crop and livestock components; (ii) to calculate the impact of maize residue practice on the succeeding crop productivity and profitability; (iii) to assess the impacts of maize crop residues on farmers' income generation and livelihood pattern; and (iv) to determine the factors responsible for the adoption of maize crop residue practices by the farmers.

\section{Materials and Methods}

The study was conducted at different villages of Ghoraghat upazila of Dinajpur district where farmers have been following maize residue practices. Focus group discussions (FGD), field surveys and key informant interviews (KII) were followed to collect primary data and information for farming operations. A total of 60 farmers were interviewed where 30 farmers were practicing maize crop residue and 30 farmers were practicing traditional farming. Data were collected from respondents using structured questionnaire. Secondary data and information from different reports, publications, notifications, etc. relevant to this study were also be collected and analyzed for this research. Two sets of questionnaire were developed, one for farmers who are following maize residue practices and the other one for the farm households involved in traditional practices.

\section{Analytical techniques}

Productivity measure: Productivity was measured as the ratio of farm's total output to its input (Huq et al., 1990). Here, both physical amount and monetary value have been used to measure productivity of maize and the succeeding crop. 
Profitability analysis: Profitability of crop production from the view point of individual farmers was measured in terms of gross return (GR), gross margin (GM), net return (NR) and benefit cost ratio (BCR) (undiscounted).

Computation of gross return: Gross return was calculated by multiplying the total volume of production of an enterprise by the average prices (the average of the farmgate price) of that product in the harvesting period (Dillon et al., 1993). The following equation was used to estimate gross return (GR):

$\mathrm{GR}=\sum_{\mathrm{i}=1}^{\mathrm{n}} \mathrm{Q}_{\mathrm{i}} \mathrm{P}_{\mathrm{i}}$

Where,

$\mathrm{GR}_{\mathrm{i}}=$ Gross return from $\mathrm{i}^{\text {th }}$ product (Tk./ha);

$Q_{i}=$ Quantity of the $i^{\text {th }}$ product (Tk./ha);

$P_{i}=$ Average price of the $i^{\text {th }}$ product $(T k . / k g)$; and

$\mathrm{i}=1,2,3 \ldots \ldots \ldots \ldots . . \mathrm{n}$.

Computation of total cost: Total cost (TC) included variable and fixed cost items involved in the production process. The total cost was estimated as follows:

$T C=\sum P_{X} X_{i} A+T F C$

Where,

$\mathrm{TC}=$ Total cost $(\mathrm{Tk} . / \mathrm{ha})$;

$X_{i}=$ Quantity of input $(\mathrm{kg} / \mathrm{ha})$;

$A=$ Area under crop production measured in hector;

$\mathrm{P}_{\mathrm{x}}=$ Per unit price $(\mathrm{Tk} . / \mathrm{kg})$; and

TFC $=$ Total fixed cost of a crop which includes cost of tools, land use cost and interest on operating capital.

Computation of gross margin and net return: Gross margin was calculated by the difference between gross return and total variable cost. Net return was calculated by the difference between gross margin and total cost. That is given below as:

$\mathrm{GM}=\mathrm{GR}-\mathrm{TVC}$ and NR $=\mathrm{GM}-\mathrm{TC}$

Where,

$\mathrm{GM}=$ Gross margin;

$\mathrm{GR}=$ Gross return;

TVC = Total variable cost;

$\mathrm{NR}=$ Net return; and

$\mathrm{TC}=$ Total cost.

Financial profitability analysis: Profitability analysis was calculated by deducting all costs (variable and fixed) from gross return. To determine the net return of succeeding crop, i.e., Aman rice production, the following equation was used in the present study:

$$
\pi=\sum_{\mathrm{i}=1}^{\mathrm{n}}(\mathrm{PyY})-\sum_{\mathrm{i}=1}^{\mathrm{n}}\left(\mathrm{P}_{\mathrm{X}_{\mathrm{i}}} \mathrm{X}_{\mathrm{i}}\right)-\mathrm{TFC}
$$

Where,

$\pi=$ Net return (Tk./ha);

$P_{y}=$ Per unit price of the product (Tk./ha);

$Y=$ Quantity of the production per hectare $(\mathrm{kg})$;

$P_{x i}=$ Per unit price of the $i^{\text {th }}$ inputs (Tk.);

$X_{i}=$ Quantity of the $i^{\text {th }}$ input per hectare $(\mathrm{kg})$;

TFC $=$ Total fixed cost (Tk.); and

$\mathrm{i}=1,2,3, \ldots \ldots \ldots . . \mathrm{n}$ (number of inputs). 
Benefit cost ratio: Benefit cost ratio $(B C R)$ was estimated as a ratio of gross return and gross cost. The formula of calculating BCR (undiscounted) is shown below:

$\mathrm{BCR}=$ Gross benefit $/$ Gross cost

Determinants for the adoption of maize residue practice: The logit model was estimated to identify the determinants for the adoption of maize residue practice. The implicit form of the model was as follows:

$Z_{i}=\beta_{0}+\beta_{1} X_{1}+\beta_{2} X_{2}+\beta_{3} X_{3}+\beta_{4} X_{4}+\beta_{5} X_{5}+\beta_{6} X_{6}+U_{i}$

Where,

$Z_{i}=$ The adoption of maize residue of $i^{\text {th }}$ farmer;

$X=$ Vector of explanatory variables;

$\beta_{0}=$ Constant $\beta_{1}, \beta_{2}, \beta_{3}, \ldots . ., \beta_{6}=$ Vector of parameter estimates; and

$\mathrm{U}_{\mathrm{i}}=$ Error term.

The dependent variable is an indicator variable for the adoption of maize residue practices taking values either 0 or 1.

The independent variables are captured as:

$\mathrm{X}_{1}=$ Household size (number);

$X_{2}=$ Age of household head (years);

$\mathrm{X}_{3}=$ Farm size;

$\mathrm{X}_{4}=$ Educational level of household head;

$\mathrm{X}_{5}=$ Farm income; and

$X_{6}=$ Non-farm income.

To address the livelihood patterns of the respondents, the sustainable livelihood framework approach including the asset pentagon (which is composed of five types of capital namely, human capital, social capital, natural capital, physical capital, and financial capital) were followed (DFID, 2000).

\section{Results and Discussion}

\section{Pattern of retention of maize residue}

The retention of crops was divided into three groups: wholly retention, partially retention and no retention. Aman rice and maize were cultivated in the study area as main crops. The weather plays an important role for the retention of maize residue. The rainy day after harvesting period increases the percentage of retention of maize residue in the study area. Maximum farmers (i.e., 78.2 percent) used whole retention method while 21.8 percent used partial retention method (Table 1).

Table 1. Pattern of retention of maize residue by the sampled farmers

\begin{tabular}{l|c|c}
\hline \multirow{2}{*}{ Crop } & \multicolumn{3}{|c}{ Percentages of farmers } \\
\cline { 2 - 3 } & Whole & Partial \\
\hline Maize & 78.2 & 21.8 \\
\hline
\end{tabular}

Source: Field survey, 2015.

\section{Retention of maize residue by the distance of plots of the homestead}

Whole retention method was highest in case of far distance to homestead for maize which was 82.8 percent and partial retention method was highest in case of no distance to homestead for maize which was 37.6 percent (Table 2). 
Table 2. Retention of maize residue by distance of plot to the homestead

\begin{tabular}{l|c|c|c|c|c|c}
\hline \multirow{2}{*}{ Crop } & \multicolumn{2}{|c|}{ No distance } & \multicolumn{2}{c|}{ Little far distance } & \multicolumn{2}{c}{ (in percentage) } \\
\cline { 2 - 7 } & Whole & Partial & Whole & Partial & Whole & Partial \\
\hline Maize & 62.4 & 37.6 & 74.5 & 25.5 & 82.8 & 17.2 \\
\hline
\end{tabular}

Source: Field survey, 2015.

\section{Utilization of maize residue}

Crop residue will be a co-product of grain production where both the grain and the residue have significant value. Several utilization options are available to the farmers for the management of residues which are: animal feed, cooking fuel, incorporation with tillage for organic fertilizer, mulching, burned at field, etc. Table 3 shows that the highest number of households utilized their maize residues as incorporation with tillage for organic fertilizer, which was 82.2 percent. The lowest number of households burned their maize residues at field, which was 1.3 percent.

Table 3. Utilization of maize residue in the study area

\begin{tabular}{l|c|c}
\hline Various uses of maize residue & Percentages of farmers & Rank in order \\
\hline Animal feed & 69.4 & 3 \\
Animal bedding & 15.7 & 5 \\
Cooking fuel & 58.3 & 4 \\
Incorporation for organic fertilizer & 82.2 & 1 \\
Burned at field & 1.3 & 7 \\
Mulching & 74.6 & 2 \\
Sold for cash & 2.5 & 6 \\
\hline
\end{tabular}

Source: Field survey, 2015

\section{Interdependences of maize residue retention and livestock rearing}

Maize residues have been used for feeding livestock for many generations and remain one of the cheapest and best ways for winter feeding. Due to maize residue practice, crop and livestock both were benefited through resources interdependences. Table 4 shows the benefit of livestock rearing for maize residue retention and the effects of the plots due to animal rearing. It was found that average milk yield was $1.3 \mathrm{l} /$ day without maize residue situation and with maize residue practice, it was $1.5 \mathrm{l} /$ day.

Without maize residue, calving period was 135.4 days and with maize residue retention, it was 142.6 days. Number of animal was also increased due to maize residue practice. On the other hand, majority of the farmers mentioned that due to animal rearing, crop fields were benefited. They used less fertilizer due to cowdung droppings. Farmers also reported that soil surface becomes loose for livestock rearing. By this way, maize residue retention and livestock rearing are being interdependent.

Table 4. Interdependences of maize residue retention and livestock rearing

\begin{tabular}{|c|c|c|c|}
\hline Items & Without residue practice & \multicolumn{2}{|c|}{ With residue practice } \\
\hline Livestock rearing with maize residue retention & & \\
\hline Average milk yield & 1.3 I/day & \multicolumn{2}{|c|}{1.5 l/day } \\
\hline Calving period & 135.4 days & \multicolumn{2}{|c|}{142.6 days } \\
\hline Number of animal & 2.5 & \multirow{2}{*}{\multicolumn{2}{|c|}{3.4}} \\
\hline Crop plots with livestock rearing & & & \\
\hline \multirow{2}{*}{ Items } & & \multicolumn{2}{|c|}{$\begin{array}{l}\text { Farm household responses } \\
\text { (in \%) }\end{array}$} \\
\hline & & Yes & No \\
\hline Less fertilizer use due to cowdung droppings & & 96.3 & 3.7 \\
\hline Loosen soil surface due to livestock grazing & & 92.4 & 7.6 \\
\hline
\end{tabular}

Source: Field survey, 2015. 


\section{Benefits from retention of maize residue}

Maize residues are good sources of plant nutrients and are important components for the stability of agricultural ecosystems. Table 5 shows that among the many benefits, 98.2 percent farmers were benefited through improving soil health which was number 1 in rank order, and 33.5 percent were benefited through controlling carbon emission which was number 8 in rank order.

Table 5. Benefits from maize residue retention

\begin{tabular}{lcc}
\hline Benefits & Responses (in percentage) & Rank in order \\
\hline Improves soil health & 98.2 & 1 \\
Reduces fertilizer use & 86.4 & 4 \\
Saves irrigation water & 93.2 & 2 \\
Controls carbon emission & 33.5 & 8 \\
Enhances productivity & 79.4 & 6 \\
Decreases soil erosion & 85.7 & 5 \\
Improves soil moisture & 88.6 & 3 \\
Increases soil holding capacity & 76.4 & 7 \\
\hline
\end{tabular}

Source: Field survey, 2015.

Impact of maize residue practice on the succeeding crop productivity and profitability

This section shows the impact of maize residue practice on the productivity and profitability of the succeeding crop i.e., Aman rice, as farmers produce Aman rice followed by maize. Table 6 reveals that per hectare yield of Aman rice was found to be $5180.4 \mathrm{~kg}$ under the situation of maize residue practice and per hectare yield of Aman rice was $3905.2 \mathrm{~kg}$ without the retention of maize residue practice in the study area. Thus, the farmers who are practicing maize residue are more productive.

Total cost was estimated at Tk. 52450.4 without maize residue retention; but under residue retention, per hectare total cost of Aman rice was estimated at Tk. 58412.3. Gross return per hectare was found to be Tk. 77127.5 without residue practices, whereas per hectare gross return was estimated at Tk. 102312.5 with the situation of residue practices.

Table 6. Productivity of succeeding crop i.e., Aman rice production

\begin{tabular}{lccc}
\hline Practices & Main product $(\mathrm{kg} / \mathrm{ha})$ & By-product $(\mathrm{kg} / \mathrm{ha})$ \\
\hline Without maize residue practice & 3905.2 & 1757.3 \\
With maize residue practice & 5180.4 & 2331.1 \\
Impact on productivity (kg/ha) & & $1275.2^{* *}$ & \\
\hline $\mathrm{t}$-value & \multicolumn{3}{c}{2.1} \\
\hline
\end{tabular}

Source: Authors' estimation based on field survey, 2015.

Note: ${ }^{* *}$ indicates significant at $5 \%$ probability level.

Gross margin was estimated at Tk. 33976.6 without maize residue and Tk. 55180.7 with maize residue management. Net returns per hectare were estimated at Tk. 24677.1 and Tk. 43900.2, respectively for the situation of without and with maize residue practices. So, profitability per hectare of maize residue management was higher than the management without maize residue. Table 7 reveals that the overall BCR (undiscounted) of Aman rice farming without residue practice was 1.5 and it was 1.8 for maize residue practice. 
Table 7. Profitability o succeeding crop i.e., Aman rice production (in Tk./ha)

\begin{tabular}{l|c|c}
\hline \multirow{2}{*}{ Cost items } & Without maize residue & With maize residue \\
\cline { 2 - 3 } & Cost (Tk.) & Cost (Tk.) \\
\hline Variable cost & & \\
Human labour & 15422.2 & 21560.4 \\
Power tiller & 5424.3 & 5350.2 \\
Seed/seedling & 3245.2 & 4069.4 \\
Irrigation & 12848.1 & 10520.5 \\
Insecticides & 650.5 & 890.6 \\
Fertilizers cost & 4540.2 & 3480.2 \\
Miscellaneous cost & 1020.4 & 1260.5 \\
A. Total variable cost & 43150.9 & 47131.8 \\
Fixed cost & & \\
Interest on operating cost & 950.5 & 1240.2 \\
Land use cost & 4936.2 & 6089.8 \\
Depreciation cost & 3412.8 & 3950.5 \\
B. Total fixed cost & 9299.5 & 11280.5 \\
C. Total cost & 52450.4 & 58412.3 \\
Product: & & \\
$\quad$ Quantity (kg/ha) & 3905.2 & 5180.4 \\
$\quad$ Price (Tk./kg) & 17.5 & 17.5 \\
By-product: & & \\
$\quad$ Quantity (kg/ha) & 1757.3 & 2331.1 \\
$\quad$ Price (Tk./kg) & 5.0 & 5.0 \\
D. Gross return & 77127.5 & 102312.5 \\
E. Gross margin (D-A) & & 55180.7 \\
F. Net return (D-C) & 33976.6 & 43900.2 \\
G. Benefit cost ratio (D/C) & & 1.8 \\
Impact on profitability (Tk./ha) & 24677.1 & \\
\hline t-value & 1.5 & \\
\hline & & \\
\hline
\end{tabular}

Source: Authors' estimation based on field survey, 2015.

Note: ${ }^{* * *}$ indicates significant at $1 \%$ probability level.

Due to maize residue practice, productivity of succeeding crop i.e., Aman rice was increased by the amount of $1275.2 \mathrm{~kg}$ per hectare and it was significant at $5 \%$ level (Table 6). Financial profitability of Aman rice was enhanced by the amount of Tk. 19223.1 and it was also significant at $1 \%$ level (Table 7). Thus, it can be concluded that productivity and profitability from Aman rice production with maize residue retention were higher than Aman rice production without maize residue practice.

\section{Impact of maize residue on income generation}

The annual gross income of the sample farmers was estimated by adding the earnings from all incomegenerating activities of the households during the references year 2014. The activities were may broadly be classified into two categories: farm income and non-farm income. It is evident from Table 8 that average annual income of farmers without maize residue management was Tk. 205297.5 and for the maize residue practicing farmers, it was Tk. 225971.4. However, total annual income of sampled farmers was increased by the amount of Tk. 20673.9 due to maize residue management and the impact of having such practice on income was statistically significant which was verified by the value of t-statistics. 
Table 8. Average annual income of sample farmers

\begin{tabular}{|c|c|c|c|c|}
\hline \multirow{2}{*}{ Sources of income } & \multicolumn{2}{|c|}{ Without maize residue practice } & \multicolumn{2}{|c|}{ With maize residue practice } \\
\hline & Amount (Tk.) & Percentage & Amount (Tk.) & Percentage \\
\hline \multicolumn{5}{|l|}{ A. Farm income } \\
\hline Crop cultivation & 77239.4 & 37.6 & 98480.7 & 43.6 \\
\hline Livestock & 41290.4 & 20.1 & 46370.2 & 20.5 \\
\hline Homestead & 4340.2 & 2.1 & 5220.5 & 2.3 \\
\hline \multicolumn{5}{|l|}{ B. Non-farm income } \\
\hline Service & 48530.4 & 23.6 & 51899.6 & 23.0 \\
\hline Business & 25430.6 & 12.4 & 17866.6 & 7.9 \\
\hline C. Others & 8466.5 & 4.2 & 6133.8 & 2.7 \\
\hline Total $(A+B+C)$ & 205297.5 & 100.0 & 225971.4 & 100.0 \\
\hline Impact on income (Tk.) & \multicolumn{4}{|c|}{$20673.9^{* * *}$} \\
\hline t-value & \multicolumn{4}{|c|}{2.6} \\
\hline
\end{tabular}

Source: Authors' estimation based on field survey, 2015.

Note: ${ }^{* * *}$ indicates significant at $1 \%$ probability level.

\section{Factors influencing the adoption of maize residue practice}

The result of logit regression model is presented in Table 9. Six variables were included in the model, which were household size, age, farm size, education, farm income and non-farm income, respectively.

Table 9. Estimates of the logistic regression of determinants of maize residue practice of farm households

\begin{tabular}{l|c|c|c|c|c}
\hline \multicolumn{1}{c|}{ Variables } & $\begin{array}{c}\text { Coefficient } \\
(\beta)\end{array}$ & $\begin{array}{c}\text { Standard } \\
\text { error }\end{array}$ & d.f. & $\begin{array}{c}\text { Level of } \\
\text { significance }\end{array}$ & $\begin{array}{c}\text { Exponential of coefficient or } \\
\text { odds ratio }\end{array}$ \\
\hline Constant & -1.282 & 2.903 & 1 & 0.659 & 2.602 \\
Household size $\left(\mathrm{X}_{1}\right)$ & -0.842 & 0.357 & 1 & 0.837 & 0.496 \\
Age $\left(\mathrm{X}_{2}\right)$ & $-0.092^{* * *}$ & 0.034 & 1 & 0.007 & 1.096 \\
Farm size $\left(\mathrm{X}_{3}\right)$ & $0.901^{* *}$ & 0.446 & 1 & 0.044 & 0.406 \\
Education $\left(\mathrm{X}_{4}\right)$ & 0.015 & 0.182 & 1 & 0.933 & 1.016 \\
Farm income $\left(\mathrm{X}_{5}\right)$ & $0.00049^{* *}$ & 0.00020 & 1 & 0.013 & 1.025 \\
Non-farm income $\left(\mathrm{X}_{6}\right)$ & $0.00012^{* *}$ & 0.00014 & 1 & 0.025 & 1.000 \\
\hline
\end{tabular}

Source: Authors' estimation based on field survey, 2015.

Note: ${ }^{* *}$ and ${ }^{* *}$ indicate significant at $1 \%$ and $5 \%$ level of probability, respectively.

\section{Household size}

Household size has a negative coefficient but it was insignificant. So, it has a minor impact on adopting maize residue management.

\section{Age of household head}

The farmers who are younger, the probability of adopting maize residue is significantly greater than who are comparatively older. If there is one unit increase in age of household head, the log odds ratio of adopting maize will decrease by 1.096 .

\section{Farm size}

The result shows that the farmers who have large farm size, the probability of adopting maize residue is significantly greater than the farmers who have less farm size. If there is one unit increase in farm size of the farmers, the log odds ratio of adopting maize will increase by 0.406 .

\section{Education level of household head}

The education level of household head has a positive coefficient which was 0.015 but it was insignificant. So, it has a minor impact on adoption of maize residue practice. 


\section{Farm income}

The Households which have higher annual average farm income, the probability of adopting maize residue is significantly greater than the lower annual average farm income households. If there is one unit increase in farm level income, the log odds ratio of adopting maize will increase by 1.025.

\section{Non-farm income}

The Households which have higher annual average non-farm income, the probability of adopting maize residue is significantly greater than the households which have lower annual average non-farm income. If there is one unit increase in non-farm level income, the log odds ratio of adopting maize will increase by 1.0 .

\section{Impact on livelihood pattern of the maize farmer}

The asset pentagon approach shows that there is a noteworthy improvement based on different capitals (namely, human capital, social capital, natural capital, physical capital and financial capital) of farm households adopting maize residue practice in comparison to without maize residue practice.

Table 10 represents the changing nature of different capitals which reveals that the farmers practicing maize residue had a positive impact on farm households' livelihood patterns in comparison to farmers without maize residue practice. The findings reveal that households practicing residue retention for succeeding crop production have higher income and better livelihood status than those who have not been practicing such. Due to practicing maize residue, remarkable improvement took place in farmers' livelihood where the difference is the highest in financial capital and lowest in natural capital (Table 10).

Table 10. Increases in capitals of sampled farm households (in percentage)

\begin{tabular}{lcccc}
\hline Items & Without maize residue & With maize residue & Difference \\
\hline Human capital & 15.3 & 23.5 & 8.2 \\
Social capital & 13.4 & 22.7 & 9.3 \\
Financial capital & 15.6 & 26.7 & 11.1 \\
Natural capital & 7.7 & 10.6 & 2.9 \\
Physical capital & 14.1 & 18.8 & 4.7 \\
\hline
\end{tabular}

Source: Authors' estimation based on field survey, 2015.

\section{Conclusion}

This study concludes that retention of maize residue significantly increased yield and yield components of succeeding crop i.e., Aman rice. Maize residue practice also improves soil moisture, reduce the use of chemical fertilizer and irrigation water. Due to maize residues practice, crop and livestock both were benefited through resource interdependences. Farmers practicing maize residue earn extra money by selling increased amount of milk. The finding of the study reveals that practicing of maize residue is more profitable. The results of logit model exhibit that among six variables, four variables are significant and these are farm size, age of household head, farm income and non-farm income. The income potential is higher under practising maize residue management; as such cultivation normally incurs less expenditure on fertilizer, pesticides and irrigation. The results of asset pentagon approach reveals that there is a significant difference of different capitals between two groups. Therefore, it can be concluded that there is great scope to improve the overall economic condition of farmers in terms of higher income and better livelihood pattern through the maize residue management practice. Finally, the study recommends for arranging relevant training pragramme and providing extension services by the concerned authority for maize residue management properly. 


\section{Acknowledgement}

The authors express gratefulness to BAURES for funding to conduct this research.

\section{References}

Bakhtiar, S.M., Alam, M.J., Mahmood, K and Rahman, M.H. 2002. Integrated nutrient management under three agro-ecological zones of Bangladesh. Pakistan Journal of Biological Sciences, 5: 390-393.

BBS. 2013. Statistical Year Book of Bangladesh, Bangladesh Bureau of Statistics, Ministry of Planning, Government of the Peoples Republic of Bangladesh, Dhaka.

Burgess, M.S., Mehuys, G.R. and Madramootoo, C.A. 2002. Nitrogen dynamics of decomposing corn residue components under three tillage systems. Soil Science Society of America Journal, 66: 1350-1358.

DFID. 2000. Northwest Fisheries Extension Project-2, Livelihood Review. Livelihood assessment of communities and households and technical assistance of aquaculture technologies and methods, Vol.:1, Department for International Development, Dhaka.

Dillon, J.L. and Hardekar, J.B. 1993. Farm management research for small farm development. Food and Agricultural Organization of the United Nations, Rome, Italy.

Huq, S., Rahman, A.A. and Conwayb, G.R. 1990. Environmental aspects of agricultural development in Bangladesh. University Press Limited, Dhaka, Bangladesh.

Khanam, M., Rahman, M.M. and Islam, M.R. 2001. Effect of manures and fertilizers on the growth and yield of BRRI Dhan 30 . Pakistan Journal of Biological Sciences, 4: 172-174.

Krishna, G.M., Arun, K.M., Kuntal, M.H., Kali, K.B., Prabir, K.G. and Manoranjan, M. 2004. Rice residue-management options and effects on soil properties and crop productivity. Journal of Food Agriculture \& environment, 2(1): 224-231.

Larson, W.E., Clapp, C.E., Pierre, W.H. and Morachan, Y.B. 1972. Effects of increasing amounts of organic residues on continuous corn: II. Organic carbon, nitrogen, phosphorus and sulphur. Agronomy journal, 64: 204-208.

Latham, M. 1997. Crop residues as a strategic resource in mixed farming systems. p. 181-196. In: Renard, C. (ed.). Crop residues in sustainable mixed crop/livestock farming systems, CAB International.

Pretty, J.N., Ball, A.S., Xiaoyun, L. and Ravindranath, N.H. 2002. The role of sustainable agriculture and renewable-resource management in reducing greenhouse-gas emissions and increasing sinks in China and India. The Royal Society, 360: 1741-1761.

Regmi, A.P., Ladha, J.K., Pathak, H., Pashuquine, E., Dawani, D., Hobbs, P.R., Joshi, D., Maskey, S.L. and Pandey, S.P. 2002. Yield and soil fertility trends in a 20 years rice wheat experiment in Nepal. Soil Science Society of America Journal, 66: 857-867. DOI: 10.2136/sssaj2002.0857.

Shafi, B.M.J., Jan, M.T. and Shah, Z. 2007. Soil C and N dynamics and maize (Zea mays L.) yield as affected by cropping systems and residue management in North-western Pakistan. Soil \& Tillage Research, 94: 520-529.

Singh, B., Chanasyk, D.S. and McGill, W.B. 1998. Soil water regime under barley with long-term tillage-residue systems. Soil \& Tillage Research, 45: 59-74.

Timsina, J., Buresh, R.J., Dobermann, Dixon, J. and Tabali, J. 2010. Strategic assessment of rice-maize systems in Asia. IRRICIMMYT Alliance A Project "Intensified Production Systems in Asia (IPSA)", IRRI-CIMMYT Joint Report, IRRI, Los Banos, Philippines.

Yaduvanshi, N.P.S. 2003. Substitution of inorganic fertilizers by organic manures and the effect of on soil fertility in rice-wheat rotation on reclaimed sodic soil in India. Journal of Agricultural Science, 140: 161-168. 